\title{
Serological Survey of 8 Bovine Viral Pathogens in Sika Deer(Cervus nippon) of Northern Japan
}

\author{
Tadao IMADA ${ }^{1)}$, Takamitsu TSUBOI ${ }^{1}$, Nobukazu TAKAHASHI ${ }^{2)}$, Takafumi HAMAOKA ${ }^{1)}$ \\ Makoto HARITANI ${ }^{1)}$, Toru MIYAMOTO ${ }^{1)}$ and Hideo MURATA ${ }^{1)}$ \\ 1) Tohoku Branch Laboratory, National Institute of Animal Health, \\ Uminai-31, Shichinohe, Kamikita-gun, Aomori 039-25, Japan \\ 2) Sendai Livestock Hygiene Service Center, Anyouji 3-11-22, Miyaginoku, Sendai, Miyagi 983, Japan \\ (1995.10.25 received, 1995.12.26 accepted)
}

\section{ニホンジカにおける 8 種類の牛ウイルスに対する抗体調査}

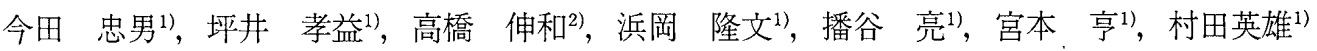 \\ 1）農林水産省家蓄衛生試験場東北支場 $\overline{\mathbf{T}} 039-25$ 青森県上北郡七戸町字海内 31 \\ 2) 宮城県仙台家畜保健衛生所 $=983$ 仙台市宮城野区安養寺 3-11-22
}

\begin{abstract}
A seroepidemiological examination of 8 bovine viral pathogens was conducted on free-ranging and farmed sika deer (Cervus nippon) of Northern Japan. Blood samples were collected from 156 of these deer at 7 locations in Aomori, Iwate and Miyagi prefectures during 1991 through 1993. Antibodies to bovine corona virus $(95 \%)$, bovine rotavirus $(45 \%)$, Akabane disease virus $(38 \%)$, bluetongue virus $(25 \%)$, parainfluenza virus-3 $(18 \%)$, bovine virus diarrhea-mucosal disease virus $(3 \%)$ and bovine herpesvirus $1(1 \%)$ were detected. No serologic reactor to bovine leukosis virus was found. The pathogenicity of these bovine viruses for the sika deer has not been well documented, but it has been suggested that these deer could be important viral reservoirs for some bovine viral pathogens in Japan.
\end{abstract}

Key words : bovine viral pathogen, reservoir, sika deer

Jpn.J.Zoo Wild.Med. 1(1): 42-44, 1996

Recently, the population of sika deer (Cervus nippon) is gradually increasing in the refuges of northern Japan $^{1)}$. There are some possibilities that deer meat is served as healthy food and velvet is utilized as a traditional chinese medicine. In the near future, deer farming will be regarded as a recognized livestock option rather than a high-cost speculative venture in the mountainous areas of Japan. On the other hand, cattle and wild deer are starting to share sympatric ranges in some prefectures. This raises the possibility that some diseases are transmitted between cattle and deer ${ }^{2-6)}$, and since wild deer can wander wide ranges, disease investigation of deer is important for intensive management of both species. The purpose of this investigation was to reveal the prevalence of selected bovine virus infections among sika deer in Japan.

Sera were collected from hunter-killed, live-trapped and farmed deer in 7 locations in northern Japan during 1991 1993. Bleeding was by cardiac puncture in hunter -killed deer and by jugular vein puncture in live-trapped and farmed deer. Sera were stored at $-20^{\circ} \mathrm{C}$ until tested. 
SEROLOGICAL SURVEY OF SIKA DEER

Table 1 Antibody prevalences and antibody titers in sika deer in Japan

\begin{tabular}{|c|c|c|c|c|c|c|c|c|}
\hline \multirow{2}{*}{ Pathogens (HI test) } & \multirow{2}{*}{ Results $^{1)}$} & \multirow{2}{*}{ Prevalence $(\%)$} & \multicolumn{6}{|c|}{ Antibody titer } \\
\hline & & & $<10$ & 10 & 20 & 40 & 80 & $160<$ \\
\hline Bovine cornavirus & $\mathrm{F}: 105 / 109$ & 96 & 4 & 4 & 10 & 24 & 36 & 31 \\
\hline ("Kanagawa" strain) & $\begin{array}{l}\mathrm{W}: 24 / 27 \\
\mathrm{~T}: 129 / 136\end{array}$ & $\begin{array}{l}89 \\
95\end{array}$ & 3 & 4 & 2 & 8 & 5 & 5 \\
\hline Bovine rotavirus & $F: 50 / 109$ & 46 & 59 & 17 & 18 & 10 & 5 & 0 \\
\hline ("Lincoln" strain) & $\begin{array}{ll}\mathrm{W}: & 11 / 27 \\
\mathrm{~T}: & 61 / 136\end{array}$ & $\begin{array}{l}41 \\
45\end{array}$ & 16 & 9 & 1 & 0 & 1 & 0 \\
\hline Parainfluenza virus-3 & $\mathrm{F}: 22 / 109$ & 20 & 87 & 7 & 8 & 6 & 1 & 0 \\
\hline ("Yamanashi" strain) & $\begin{array}{lc}\mathrm{W}: & 3 / 27 \\
\mathrm{~T}: & 25 / 136\end{array}$ & $\begin{array}{l}11 \\
18\end{array}$ & 24 & 2 & 1 & 0 & 0 & 0 \\
\hline
\end{tabular}

${ }^{1)}$ Number positive/number tested, $\mathrm{F}:$ farmed deer, $\mathrm{W}:$ wild deer, $\mathrm{T}:$ total.

Deer sera were tested for antibodies against bovine corona virus $(\mathrm{BCV})$, bovine rotavirus $(\mathrm{BRV})$, parainfluenza virus-3(PI-3), Akabane disease virus(AV), Bluetongue virus (BTV), bovine virus diarrhea -mucosal disease virus(BVD-MDV), bovine herpesvirus-1(BHV-1) and bovine leukosis virus $(B L V)$. The hemagglutination inhibition(HI) test was employed for the detection of BCV, BRV and PI-3 antibodies ${ }^{7)}$. Titers of 1:10 or greater were regarded as positive. A serum neutralization test in microplates was used for the detection of AV, BTV, BVD-MDV and BHV-1 antibodies $^{8)}$ in which the positive threshold titer was 1 : 4. The agar gel precipitation(AGP) test was used to detect precipitin antibody activity to BLV ${ }^{9)}$. Titers of 1:1 or greater were regarded as positive. All sera were inactivated at $56^{\circ} \mathrm{C}$ for $30 \mathrm{~min}$, and some were treated with Kaolin ${ }^{7)}$ for HI test.

The results of serological tests are shown in Tables 1 and 2. Most of the sika deer $(95 \%)$ had antibodies against $\mathrm{BCV}$, while very few animals showed positive reactions to $\mathrm{BVD}-\mathrm{MD}(3 \%), \mathrm{BHV}-1(1 \%)$ and $\mathrm{BLV}$ $(0 \%)$. The prevalence of BRV, AV, BTV and PI-3 antibodies were 45,38, 25 and $18 \%$, respectively. There was a statistically significant difference in AV antibody prevalence between wild and farmed deer. AV antibodies were more prevalent in wild deer $(\mathrm{P}<0.01$; Table 2).
In the present investigation, we detected antibodies against some kinds of bovine viruses that are pathogenic for cattle in the sika deer of Japan. The presence of serologic reactors indicated that some animals had been exposed to agents that are related or identical to the seven livestock pathogens used in these serological tests. In some prefectures, deer can freely wander the pastures. The prevalence of antibodies in deer correlated with those of cattle reared in the same areas except for BTV and BVD-MDV antibodies (personal communications). In this area, there were few BTV antibodies in cattle, but it was reported that American deer had BTV antibody and epizootic hemorrhagic disease virus (EHDV) which belonged to genus orbivirus ${ }^{3,4,6)}$. It is then presumed that a virus with a common antigenicity of BTV might be prevalent in these areas ${ }^{10)}$. The high prevalences of antibodies against $\mathrm{BCV}, \mathrm{BRV}$ and $\mathrm{AV}$ would indicate that the sika deer in these areas are a reservoir of these viruses, and suggest the need for more detailed investigations to determine their actual pathogenic role for wild ungulates.

The authors are grateful to Mr. T. Syouji and Mr. K. Yatuhashi for their technical assistance. This work was supported in part by an Integrated Research Program for Effective Use of Biological Activitites to Create New Demand(Bio-Renaissance Program) from the Ministry of 
Tadao IMADA et al.

Table 2 Antibody prevalences and antibody titers in sika deer in Japan

\begin{tabular}{|c|c|c|c|c|c|c|c|c|}
\hline \multirow{2}{*}{ Pathogens (SN test) } & \multirow{2}{*}{ Results $^{1)}$} & \multirow{2}{*}{ Prevalence $(\%)$} & \multicolumn{6}{|c|}{ Antibody titer } \\
\hline & & & $<4$ & 4 & 8 & 16 & 32 & $64<$ \\
\hline \multirow{3}{*}{$\begin{array}{l}\text { Akabane disease virus } \\
\text { ("OBE-1" strain) }\end{array}$} & $\mathrm{F}: 23 / 90$ & $26^{2)}$ & 67 & 13 & 2 & 1 & 1 & 6 \\
\hline & $W: 29 / 47$ & $62^{2)}$ & 18 & 13 & 4 & 1 & 10 & 1 \\
\hline & $\mathrm{T}: 52 / 137$ & 38 & & & & & & \\
\hline \multirow{3}{*}{$\begin{array}{l}\text { Bluetongue virus } \\
\text { ("Type-1") }\end{array}$} & $F: 21 / 90$ & 23 & 69 & 15 & 4 & 2 & 0 & 0 \\
\hline & $\mathrm{W}: 13 / 47$ & 28 & 34 & 8 & 3 & 1 & 1 & 0 \\
\hline & $\mathrm{T}: 34 / 137$ & 25 & & & & & & \\
\hline \multirow{3}{*}{$\begin{array}{l}\text { Bovine virus diarrhea- } \\
\text { mucosal disease virus } \\
\text { ("Nose" strain) }\end{array}$} & $\mathrm{F}: \quad 2 / 51$ & 4 & 49 & 1 & 0 & 0 & 1 & 0 \\
\hline & $W: \quad 0 / 27$ & 0 & 27 & 0 & 0 & 0 & 0 & 0 \\
\hline & $\mathrm{T}: \quad 2 / 72$ & 3 & & & & & & \\
\hline \multirow{3}{*}{$\begin{array}{l}\text { Bovine herpesvirus } 1 \\
\text { ("Los Angeles" strain) }\end{array}$} & $\mathrm{F}: \quad 2 / 90$ & 2 & 88 & 0 & 0 & 1 & 0 & 1 \\
\hline & $W: \quad 0 / 47$ & 0 & 47 & 0 & 0 & 0 & 0 & 0 \\
\hline & $\mathrm{T}: \quad 2 / 137$ & 1 & & & & & & \\
\hline
\end{tabular}

${ }^{1)}$ Number positive/ number tested, ${ }^{2)} \mathrm{P}<0.01, \mathrm{~F}:$ farmed deer, $\mathrm{W}:$ wild deer, $\mathrm{T}:$ total

Agriculture, Forestry and Fisheries of Japan (BRP 95-VI-A $-(2))$.

\section{要 約}

東北地方に生息する野生シカと飼育シ力の血清 (156 例) について,牛ウイルスに対する抗体保有状況を調査した。そ の結果，コロナ (95\%)，ロ夕 (45\%)，アカバネ病 $(38 \%)$, ブルータング $(25 \%)$, パラインフルエンザ $(18 \%)$, 牛下 痢粘膜病 $(3 \%)$ および牛へルペス 1 型（1\%）に対する抗 体が検出され，牛白血病ウイルスに対する抗体は検出され なかった。この地方においてウイルスレゼルボアとしてシ カを認識する必要が示唆された。

\section{REFERENCES}

1.Oi T,Suzuki M, Horino S, Miura S.1993.Comparison of aerial and ground counts for wild sika deer(Cervus nippon). Honyurui Kagaku (Mammalian Science) 33:1-8.

2.Giovannini A,Cancellotti FM, Turilli C, Randi E.1988. Serological investigation for some bacterial and viral pathogens in fallow deer (Cervus dama) and wild boar (Sus scrofa) of the San Rossore Preserve, Tuscany, Italy. J Wildl Dis 24:127-132.
3. Johnson JL, Barber TL, Frey ML, Nason G.1986. Serological survey of selected pathogens in white-tailed and mule deer in Western Nebraska. J Wildl Dis 22:515-519.

4.Kocan AA, Castro AE, Shaw MG, Rogers SJ.1987. Bluetongue and epizootic hemorrhagic disease in white-tailed deer from Oklahoma: Serologic evaluation and virus isolation. Am $J$ Vet Res 48: 1048-1049.

5. Lamontagne L, Sadi L, Joyal R. 1989. Serological evidence of bovine herpesvirus 1-related virus infection in the white-tailed deer population on Anticosti Island, Quebec. J Wildl Dis 25:202-205.

6. Waldrup KA, Collisson E, Bentsen SE, Winkler CK, Wagner GG.1989. Prevalence of erythrocytic protozoa and serologic reactivity to selected pathogens in deer in Texas. Pre Vet Med 7:49-58.

7.Sato K, Inaba Y, Kurogi H,Takahashi E, Satoda K,Omori T, Matumoto M.1976. Hemagglutination by calf diarrhea coronavirus. Vet Microbiol 2:83-87.

8. Shimizu M, Satou K, Nishioka N, Yoshino T, Momotani E, Ishikawa Y.1989.Serological characterization of viruses isolated from experimental mucosal disease. Vet Microbiol 19:13-21.

9.Miller JM, Van der Maaten MJ.1976. Serologic detection of bovine leukemia virus infection. Vet Microbiol 1:195-202.

10. Campbell CC, Barber TL, Jochim MM.1978. Antigenic relationship of ibaraki,bluetongue, and epizootic hemorrhagic disease viruses. Vet Microbiol 3:15-22. 